\title{
Wales at Westminster: Parliament, Principality and Pressure Groups, 1542-1601 ${ }^{\star}$
}

\author{
LLOYD BOWEN \\ Cardiff University
}

This article attempts to address an inconsistency of modern historiography regarding the legacy of Wales's union with England in the mid-sixteenth century. The discrepancy concerns the participation of Welshmen in the new parliamentary and administrative roles afforded by the union. The Henrician statutes which united Wales with England remodelled Welsh justice and administration, bringing Wales into line with English practice. Justices of the peace were introduced, Wales was divided into shires like England, and, in the most symbolically significant demonstration of the incorporation of Wales into the English body politic, 26 (later 27) Welsh borough and county constituencies were enfranchised and allowed to send representatives to the national parliaments at Westminster. ${ }^{1}$ However, the speed of the reception and adoption of these new rights by Welshmen has not been seen as uniform. Whereas they are often portrayed as embracing their new administrative roles quickly and with enthusiasm, their participation in parliamentary business is seen as halting, uncertain and ineffective. ${ }^{2}$ This generally has led to the characterization of the Welsh as lacking interest in parliament and continuing to be unsure of its mechanisms and procedures for many decades after their enfranchisement. ${ }^{3}$ This article examines how the 'two-speed' adoption of the union has become an accepted element of modern historiography, and suggests that this case has been overstated.

The picture of a hesitant body of Welsh members in the Tudor Commons is attributable mainly to Professor A. H. Dodd, the most influential scholar of sixteenthand seventeenth-century Welsh parliamentary politics. In a seminal article of 1942, he characterized the Welsh members as serving an 'apprenticeship' in parliament which

\footnotetext{
^ I am most grateful to Alasdair Hawkyard, Simon Healy and Dr Stephen Roberts for reading an earlier draft of this article and for their valuable comments and suggestions. I would like to thank the duke of Northumberland for permission to consult and cite from his family's papers at Alnwick Castle.

${ }^{1}$ Alasdair D. K. Hawkyard, 'The Enfranchisement of Constituencies', ante, X (1991), 8-9. This figure includes Monmouthshire which was made part of the English assize system and was under the jurisdiction of the chancery and exchequer at Westminster.

2 John Gwynfor Jones, Early Modern Wales, c.1525-1640 (Basingstoke, 1994), pp. 87-90, 178-86; Howell A. Lloyd, The Gentry of South-West Wales, 1540-1640 (Cardiff, 1968), pp. 93, 107, 112; W.R.B. Robinson, 'The Tudor Revolution in Welsh Government, 1536-1542: Its Effects on Gentry Participation', E.H.R., CIII (1988), 1-20; Calendar of the Catmanonshire Quarter Sessions Records, 1541-1558, ed. W. Ogwen Williams (London and Bradford, 1956), pp. xvi, xxiii, xliv-v.

${ }^{3}$ Lloyd, Gentry, ch. 3 (i); Tim Thomton, 'Dynasty and Territory in the Early Modern Period: The Princes of Wales and their Western British Inheritance', Welsh History Review, XX (2000), 18-19.
} 
he extended down to 1625 , over 80 years after their enfranchisement. ${ }^{4}$ Sir Geoffrey Elton, meanwhile, turned his attention to Wales's activity in mid-sixteenth-century parliaments in an article of 1984 , which revised a number of Dodd's conclusions but did little to alter the picture of the Welsh as the poor cousins of Englishmen at Westminster. ${ }^{5}$ Consideration shall be given to Dodd and Elton's approaches before going on to offer evidence which indicates that, although the Welsh were far from effective or frequent parliamentary contributors, their role in Tudor parliaments was not as negligible as has been alleged. Moreover, it will be argued that they were aware of legislative tactics and procedure, and had definite ideas about the accountability of Welsh members as representatives of their constituencies.

Professor Dodd emphasized the early Welsh members' requests for leave of absence from the house, and their desire to take advantage of the immunities and privileges which attended membership. As the first glimpses of Welsh 'activity' in the Commons, he cited such instances as evidence of the Welsh members' superficial engagement with parliament. ${ }^{6}$ However, such an approach fails to address the fact that the early Commons Joumal generally recorded procedural rather than political contributions, helping generate the impression of a Welsh membership whose main aim was to return home as soon as possible. ${ }^{7}$ Dodd also passed quickly over minor legislative measures of Welsh interest, dismissing them as 'bills of no great moment', local matters which did not engage his attention as much as the constitutional conflicts he emphasized. ${ }^{8}$ Elton, meanwhile, cast his eye over the bills and acts concerning Wales in parliament between 1542 and 1581 . He was not impressed by what he found, concluding that Welsh activity was 'unsystematic', that the principality had not 'found its novel connexion with the sovereign legislature of the realm particularly interesting', and ultimately that there was 'no determined exploitation [by Welsh members] of the possibilities ... [which] must call into doubt whether an entity to be called Wales had much reality in the middle of the sixteenth century'.

Although this article will not argue for any concerted or systematic Welsh involvement in the period, it will nevertheless suggest that Welsh attitudes towards parliament may not have been as indifferent as has been hitherto thought. Firstly, evidential problems must be addressed as the Journals of the Lords and Commons are so thin as to provide little indication of actual activity in either house. It would appear unjust, therefore, to denigrate Welsh interest in parliament from this meagre record. This situation is compounded by the dearth of family papers from sixteenth-century

\footnotetext{
${ }^{4}$ Arthur H. Dodd, 'Wales's Parliamentary Apprenticeship (1536-1625)', Transactions of the Honourable Society of Cymmrodorion (1942), 8-72.

${ }^{5}$ Geoffrey R. Elton, 'Wales in Parliament, 1542-1581', in his Studies in Tudor and Stuart Government and Politics. IV (Cambridge, 1992), pp. 91-108. See also Philip S. Edwards, 'The Parliamentary Representation of Wales and Monmouthshire, 1542-1558', University of Cambridge, Ph.D., 1970, pp. 83-4, 167-8.

${ }^{6} \mathrm{He}$ described parliamentary privileges as the 'initial attractions' of membership: Arthur H. Dodd, 'The Pattern of Politics in Stuart Wales', Transactions of the Honourable Society of Cymmrodorion (1948), 12.

7 John E. Neale, 'The Commons' Journals of the Tudor Period', Transactions of the Royal Historical Society, 4th ser., III (1920), 141-2; Geoffrey R. Elton. The Parliament of England, 1559-1581 (Cambridge, 1986), pp. 7-8.

${ }^{8}$ Dodd, 'Parliamentary Apprenticeship', pp. 8-14; idem, 'Pattern of Politics', p. 12. Cf. David Dean, 'Sir Symonds D'Ewes's Bills of "No Great Moment"', ante, III (1984), 157-9.

${ }^{9}$ Elton, 'Wales', pp. 91-2.
} 
Wales which means that the principality's members lack an evidential support which has illuminated other parliamentary business such as that undertaken by interests in London. ${ }^{10}$ It is significant in this respect that the picture of Welsh parliamentary ennui can be modified in the few instances where background material does exist, indicating the dangers of assessing Welsh interest in parliament from official or institutional records alone.

In addition, Dodd's excessively brief examination of Welsh local business which came before parliament, served to downgrade one function of the assembly which has been emphasized increasingly by scholars, like Elton, in recent years. However, Elton's own approach has led to a distortion of Welsh 'activity', on account of his principal focus upon legislation over and above debates and political context. Further, his inclination to concentrate upon the records produced by parliament itself, especially the Journals of the two houses, bills and acts, meant he was less disposed to consider evidence of parliamentary engagement afforded by other sources. ${ }^{11}$ Also he was not particularly interested in the local context of many initiatives, but it is here that we find some of the most revealing evidence for the motivation behind many of the measures which appeared in parliament, and such material gives us valuable insights into Welsh attitudes towards parliament and its perceived potentialities.

It should also be noted that both Dodd and Elton judged Welsh parliamentary activity in terms which emphasized action by Welsh members as a coherent unit. Dodd attempted to trace a Welsh 'interest' in the Commons through committee nominations, but these were only recorded systematically years after Welsh enfranchisement and do not necessarily indicate concerted involvement in any event. ${ }^{12}$ As a result, the impression of an uninterested body of M.P.s progressed naturally from his stated frame of reference. Although Elton criticised this aspect of Dodd's work, he nevertheless acknowledged that he himself had expected to find legislation promoted by Welsh members as by other 'identifiable interests'. ${ }^{13}$ Possibly unwittingly, therefore, Elton intimated that he was looking for corporate action by Welsh M.P.s, a position built upon the modern view of Wales as a political unit rather than the early modern reality of a country possessing geographical and cultural barriers which mitigated against the construction of a Welsh political 'interest'. ${ }^{14}$ The Welsh members were not a compact and coherent group possessing strong familial

${ }^{10}$ Helen Miller, 'London and Parliament in the Reign of Henry VIII', B.I.H.R., XXXV (1962), 128-49; Ian Archer, 'The London Lobbies in the Later Sixteenth Century', Historical Journal, XXXI (1988), 17-44; David Dean, 'Public or Private? London, Leather and Legislation in Elizabethan England', ibid., 525-48; idem, 'London Lobbies and Parliament: The Case of the Brewers and Coopers in the Parliament of 1593', ante, VIII (1989), 341-65.

${ }^{11}$ Conrad Russell, 'The Prisoner of his Documents?', Times Higher Educational Supplement (9 Jan. 1987), p. 16; Pauline Croft, 'The Parliament of England', Transactions of the Royal Historical Society, 6th ser., VII (1997), 225-34.

${ }^{12}$ On this point, see Chris R. Kyle, " "It will be a Scandal to Show what We Have Done with Such a Number": House of Commons Committee Attendance Lists, 1606-28', in Parliament, Politics and Elections, 1604-1648, ed. idem (Camden Soc., 5th ser., XVII, 2001), pp. 179-235.

${ }^{13}$ Elton, 'Wales', p. 91. See also his observation (p. 95), 'Wales used Parliament only a little, but it used it'.

${ }^{14}$ On the heterogeneous nature of early modern Wales, see Philip Jenkins, A History of Modern Wales, 1536-1990 (Harlow, 1992), pp. 1-13. 
interrelationships as found in constituencies such as Devon. ${ }^{15}$ In the Welsh instance, a more fruitful approach is to examine the context and progress of parliamentary business which affected Welsh interests, while acknowledging that these often engaged only discrete sections of Welsh opinion both within and outside parliament. Elton was also keen only to recognize those measures promoted by Welsh members in parliament, making a strict (and rather artificial) distinction between this and officially-sponsored business, despite the fact that the latter could have arisen from, or been influenced by, Welsh interests. As judged by these criteria, therefore, Wales did indeed appear uninterested and only fitfully engaged in parliamentary business. However, if a closer examination is made of Welsh members' activity in 'Tudor parliaments, this picture can be revised, revealing that Welsh interest groups could use parliament in subtle and effective ways. This challenges the received notion of a parliamentary 'apprenticeship' of naive novices extending down to the mid-1620s.

The engagement of Welsh interests at Westminster is apparent immediately on the arrival of Welsh members there in 1542. During this parliament's second session the first 'act of union' of 1536 was modified in a number of ways by a substantial piece of legislation, and it seems clear that several of its provisions were responses to pressure which emanated from within the principality. ${ }^{16}$ For example, Haverfordwest, the most prosperous town in Pembrokeshire, was enfranchised as a county in its own right by this second 'act of union'. This was not simply a government initiative embodied in a piece of official legislation, however. The Elizabethan antiquary, George Owen, tells us how enfranchisement was secured through the efforts of Sir Thomas Jones, the representative for Pembrokeshire, 'for favour he did bare, being a neere neighbour to the towne'. ${ }^{17}$ Owen also makes it clear that Jones was the driving force behind another provision of this act which transferred to Carmarthenshire several lordships which had been constituted part of Pembrokeshire by the 1536 legislation. Jones was a Carmarthenshire man who acquired properties in Pembrokeshire and lived there at the time of his election. Intending to 'worke his native countrie ... some good', Jones entreated the Carmarthenshire knight (whose name is unknown) to have the lordships transferred from Pembrokeshire. Owen noted that as Pembrokeshire's representative Jones 'should have withstood the same', so the lands 'were lost before any Pembrokeshire man knew therof'. ${ }^{18}$ Although writing during Elizabeth's reign, Owen's remarks reveal that he believed Jones should have furthered the interests of the county which had elected him. That this concept of representation was present at this stage challenges the view that Welshmen were slow to accommodate themselves to parliament and the opportunities it afforded.

\footnotetext{
${ }^{15}$ David Dean, 'Locality and Parliament: The Legislative Activities of Devon's M.P.s During the Reign of Elizabeth', in Tudor and Stuart Devon. The Common Estate and Government, ed. Todd Gray, Margery Rowe and Audrey Erskine (Exeter, 1992), pp. 75-95.

${ }^{16}$ Elton acknowledged possible Welsh pressure, but devalued this in his assertion that the statute simply was 'government policy': Elton, 'Wales', pp. 91-2. Cf. Peter R. Roberts, "“A Breviat of the Effectes Devised for Wales", c. 1540-41', Camden Miscellany, XXVI (Camden Soc., 4th ser., XIV, 1975), pp. 34-5.

${ }^{17}$ George Owen, Description of Penbrokeshire, ed. H. Owen (4 vols, 1892-1936), III, 113; S. T. Bindoff, The History of Parliament. The House of Commons, 1509-1558 [hereafter H.P., 1509-58], (3 vols, 1981), II, 453-4.

${ }^{18}$ Owen, Penbrokshire, III, 104-5.
} 
In addition, it is difficult to see some of the statutes and provisos passed during this first parliament to include Welsh members as simply 'official' measures. The act translating lordships to Flintshire from Denbighshire, where they had been assigned by the first union legislation, may well have had a similar history to the Pembrokeshire lands discussed above. Its attested purpose to address the fact that the lordships had 'of olde tyme been reputed and accepted ... as parte and parcell of the countie of Flynte', suggests that local knowledge had been brought to bear at some point during its passage. ${ }^{19}$ Similarly the act of 1544 which allowed greater scope for the rebuilding of decayed houses provided for a number of Welsh towns, and it would appear reasonable to assume that local pressures, or at least the initiatives of some Welsh members, occasioned their inclusion. ${ }^{20}$ Another Welsh measure which evidently arose from local concerns was the act for the true making of Welsh frieze and cottons. The act was designed to safeguard the clothmakers of Cardiganshire, Carmarthenshire and Pembrokeshire from 'foreyners' whose practices had caused 'greate decaie and ruyne' in these localities. ${ }^{21}$ Although the bill may have had official support, it was a clear instance of an identifiable economic group taking advantage of representation in parliament to address specific concerns. ${ }^{22}$ It is noteworthy that, as in many subsequent cases, this act applied to a particular area of the principality, the south-west, rather than the country as a whole. Wales was a large geographical region with a varied economic profile, so it is not surprising that such measures were location-specific rather than the product of any 'Welsh interest' in the Commons.

Bills modifying aspects of the union continued to be introduced throughout the Tudor and Stuart periods. Some historians have portrayed these measures as simply attending to 'loose ends left dangling by previous legislation', but this fails to take into account the particular pressures behind many of these bills and the connexions they reveal between constituency concerns and parliamentary action. ${ }^{23}$ Several of the attempts to alter the location of Welsh county days or quarter sessions, for example, were products of local conditions and power struggles. ${ }^{24}$ In October 1553 Thomas Somerset, who sat for Monmouthshire, was the moving force behind a bill for the county days to be held at Usk rather than Monmouth or Newport. His initiative appears to have arisen from the fact that Usk was near to Raglan, the home of his brother, the third earl of Worcester, and thus would allow the county days to be more amenable to his influence than their original locations as specified in the union legislation. ${ }^{25}$ Similar considerations appear to have been behind an act of 1553, providing for the county day of Cardiganshire to alternate between Cardigan and Aberystwyth rather than remain solely at the county town. ${ }^{26}$ It is unsurprising, therefore, that the knight of the shire on this occasion, John Price, resided at

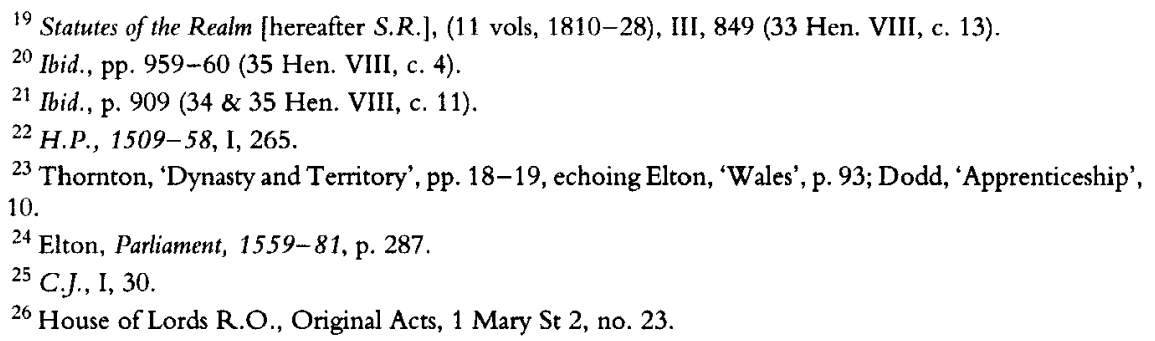


Gogerddan near Aberystwyth, a considerable distance from Cardigan. That Price's election in September 1553 was challenged and alleged to have been held without notice, should alert us to the fact that this measure probably was designed to increase his influence over the county seat. ${ }^{27}$ Gentry disputes in Anglesey, meanwhile, caused one faction to promote a bill in parliament in 1549 which removed the administrative centre of the island from the decayed 'vyllage' of Newborough to Beaumaris. ${ }^{28}$ Two groups of competing gentry fought over parliamentary representation and power on the island, and the act was secured by the Bulkeley faction of Beaumaris through their representative in the Commons, William Bulkeley, and the earl of Warwick in the Lords. The statute denied the opposing group any contributory rights in the borough election. ${ }^{29}$ The Bulkeleys also achieved an important victory by having the county's quarter sessions and assizes transferred to Beaumaris, although their adversaries later sought to overthrow this, claiming that they were unaware any statute had passed to this effect. ${ }^{30}$ Although the motivation behind a bill promoted in 1552 to make New Radnor the sole county town of Radnorshire (it shared the honour with Presteigne) is not as clear as in the Anglesey case, it may be significant that the knight during this parliament lived in New Radnor. ${ }^{31}$

Another struggle over the location of the quarter sessions arose in Caernarvonshire during the reign of Elizabeth. In December 1585 a bill was introduced which allowed Caernarvon the exclusive privilege of hosting the county's quarter sessions. In an example of how Welsh interests could mobilize in an effort to stymie parliamentary measures affecting them, the burgesses of Conway, who shared the quarter sessions with Caernarvon, petitioned Lord Treasurer Burghley after the bill had passed both houses. ${ }^{32}$ The petitioners made it plain that the bill's promoters were the county and borough members, and maintained that the Conway burgesses had not been able to put their case in parliament. Averring that the sessions brought wealth to their 'decayed' town, the burgesses requested that Burghley 'move her Maiestie to stay from geving the royall assent' to the bill. ${ }^{33}$ Their entreaties were successful as the queen vetoed the measure after it had passed both houses. ${ }^{34}$ The use of such tactics suggests a degree of sophistication and understanding of parliamentary business in Tudor Wales which has been neglected in recent accounts.

\footnotetext{
${ }^{27}$ Edwards, 'Parliamentary Representation', pp. 75-7.

${ }^{28}$ House of Lords R.O., Original Acts, 2 \& 3 Edw. VI, no. 54; P.R.O., C89/4/10.

${ }^{29}$ Philip S. Edwards, 'Crynrychiolaeth a Chynnen: Agweddau ar Hanes Seneddol a Chymdeithasol Sir Fôn yng Nghanol yr Unfed Ganrif ar Bymtheg', Welsh History Review, X (1980), 62-8. The Newborough member, John ap Robert Lloyd, probably moved the proviso in the act which freed Newborough from paying the Beaumaris member: House of Lords R.O., Original Acts, $2 \& 3$ Edw. VI, no. 54.

${ }^{30}$ P.R.O., STAC 4/4/57; 4/8/6.

${ }^{31}$ C.J., I, 18. Pembroke also attempted to obtain the sole right to hold the county quarter sessions in 1559: ibid., pp. 55, 58.

${ }^{32}$ L.J., II, 71-2, 81; Protedings in the Parliaments of Elizabeth I, ed. Terence E. Hartley (3 vols, Leicester, 1981-92), II, 75-6, 82; Sir Symonds D'Ewes, The Joumals of all the Parliaments During the Reign of Queen Elizabeth (1682), pp. 342, 343; David Dean, Lau-Making and Society in Late Elizabethan England (Cambridge, 1996), p. 253.

${ }^{33}$ P.R.O., SP $12 / 176$, f. $162 \mathrm{r}-\mathrm{v}$.

34 Proceedings, ed. Hartley, II, 103. For later concerns over the transfer of the sessions in the county, see National Library of Wales [hereafter N.L.W.], MS 9060E/1322.
} 
Evidence of Welsh members promoting regional interests through parliament is a powerful argument for the early acceptance and utilization of the institution by the Welsh gentry. It should also encourage us to question whether Welsh members were as universally apathetic as modern historian have portrayed them. Indeed, perhaps we should be surprised that they used the institution of parliament at all as it met only infrequently and securing an act was a difficult and expensive process, and this was especially the case for regions such as Wales which were distant from London. ${ }^{35}$ Nevertheless, it is clear that on occasion members did attempt to prosecute local matters in the assembly. During Mary's reign, for example, an act was passed which extended the statue of sewers to address problems caused by the inundation of sand along the Glamorganshire coast. ${ }^{36}$ The act recorded the "greate hurte, nuysaunce and losse' incurred by the inhabitants of the county, and was committed to Sir Thomas Stradling of St Donat's, Glamorganshire, who sat for a Surrey borough. ${ }^{37}$ Despite not actually sitting for a Welsh constituency, therefore, it is apparent that Stradling was acting on behalf of his neighbours in Glamorganshire who were affected by this grievance. Glamorganshire concerns were also apparent in November 1554, when a bill for making Welsh friezes was committed to Sir Edward Carne of Ewenni, the county's knight. ${ }^{38}$ During the first Elizabethan parliament, meanwhile, an act was passed which attempted to ensure the payment of custom duties by allowing the landing of merchandize only during daylight hours and under the supervision of customs officers. A proviso was included which guaranteed customs privileges granted to Anglesey, Caernarvonshire and Flintshire by Henry VIII. ${ }^{39}$ It seems clear that the amendment had been sponsored by a member or members from North Wales who wished to safeguard local rights threatened by the act. ${ }^{40} \mathrm{~A}$ more controversial instance of local advocacy can be found in the second session of the 1586 parliament, when Edward Dunn (or Dwnn) Lee, the puritan member for Carmarthen, acquainted the house with the perilous state of religion in his neighbourhood. ${ }^{41}$ On 28 February 1587 he introduced the Supplication of the Welsh radical John Penry, and informed the Commons of the 'great idolatry' in Wales, how service was said in 'nether Waylch nor Inglishe tonge' and that the populace lacked learned ministers. ${ }^{42}$ His actions brought him into serious trouble with the authorities and he was removed from the Carmarthenshire commission of the peace, but in a letter to the lord chancellor

\footnotetext{
${ }^{35}$ Elton, Parliament, 1559-81, pp. 55-8; Dean, Law-Making, p. 7; Robert Tittler, 'Elizabethan Towns and the "Points of Contact": Parliament', ante, VIII (1989), 276-8.

${ }^{36}$ For this problem, see Sir John Stradling, The Storie of the Lower Borowes of Merthyrmawr, ed. H. J. Randall and William Rees (South Wales and Monmouth Record Society, I, 1932), p. 51; Glamorgan County History IV, Early Modem Glamorgan, ed. Glanmor Williams (Cardiff, 1974), pp. 9, 42.

${ }^{37}$ Stradling's appointment is omitted in the published journal: S.R., IV, 235 (1 Mary, c. 11); L.J., I, 462; C.J., I, 36; House of Lords R.O., MS Commons Journal 1547-67, f. $77 \mathrm{v}$. I owe the last reference to Alasdair Hawkyard.

${ }^{38}$ C.J., I, 38. For other Welsh cloth measures, see Elton, 'Wales', pp. 95-6.

${ }^{39}$ S.R., IV, 374 (1 Eliz. I, c. 11); Elton, Parliament, 1559-81, p. 256.

${ }^{40}$ This may have been related to the farm of the prisage and butlerage on imported sweet wines which were an important commodity in this area and a specific concern of the act.

${ }^{41}$ P. W. Hasler, The History of Parliament. The House of Commons, 1559-1603 (3 vols, 1981), II, 48; Glanmor Williams, Wales and the Reformation (Cardiff, 1997), pp. 272, 304-6.

42 Proceedings, ed. Hartley, II, 390-1.
} 
explaining his conduct, he maintained 'I did cheiflie desier that provision might have bene made for sume convenient number of learned prechers to be resident in the cuntrie, affirminge that there was not then one within the cuntries of Carmarthen and Cardigan'. ${ }^{43}$ Dunn Lee's comments demonstrate that his actions in parliament were designed chiefly to address a local grievance of which he could make personal testimony. Even if he was operating as a member of the puritan group within the Commons, this should not blind us to the fact that he was concerned primarily with the spiritual welfare of his constituents and that he believed parliament to be an appropriate forum in which to raise the matter and obtain redress. Indeed as a puritan many of the 'official' avenues of influence were closed to him, and parliament represented one of the few places where he could articulate his concerns. ${ }^{44}$ Such instances suggest that the principality's M.P.s recognized that their election placed a duty upon them to promote the 'common weal' and be responsive to the needs of their localities.

Although it has been suggested that scouring Tudor parliamentary records for traces of a 'Welsh interest' is not to much purpose, it must be admitted that where measures affected the principality as a whole and on an equal basis, some form of common response could be forthcoming. ${ }^{45}$ This was especially the case with general taxation, for which Wales became liable after enfranchisement. The country also had to pay a customary levy called the 'mise' on the accession of a new monarch, and it would appear that Welshmen made their case to parliament for exemption from the subsidies while this was being collected. This first occurred at the accession of Edward VI when the extraordinary tax of 1549 included a proviso added in the Lords suspending collection in Wales until the mises had been gathered, thus saving the Welsh taxpayers from a double burden. ${ }^{46}$ In 1559 when new mises fell due after Elizabeth's accession, the inhabitants of Wales and the palatinate of Chester petitioned the Lords requesting a suspension of subsidy payments until their feudal obligations were discharged. ${ }^{47}$ As a consequence the emergent subsidy act of 1559 incorporated their request for exemption, and the payment of subsidies in Wales was also suspended in $1563 .{ }^{48}$ The petition of 1559 was framed in the name of the inhabitants of the whole of Wales as it was a burden incurred by all counties, and it is reasonable to assume that this kind of co-operative effort would have been forged amongst the principality's representatives while they attended parliament. Certainly it is difficult to envisage another arena where collaborative action of this kind could have been

${ }^{43}$ B.L., Add. MS 48064, ff. 144-5.

${ }^{44}$ I am grateful to Simon Healy for this point.

${ }^{45}$ George Owen, for example, when discussing the inconvenience of accounting for subsidies in the distant exchequer, discussed a project to have the money paid to the local receiver, adding he believed 'ye knights and burgesses of Wales in parliament' could obtain this through concerted action: Penbrokshire, ed. Owen, III, 69. He also envisaged Welsh members joining together for reformation of matters affecting the whole of Wales: ibid., p. 114.

${ }^{46}$ Eiton, 'Wales', p. 94; S.R., IV, 93 ( 2 \& 3 Edw. VI, c. 36).

${ }^{47}$ B.L., Cotton MS Titus F1, f. 17; D'Ewes, Journals, p. 20; L.J., I, 549.

${ }^{48}$ S.R., IV, 396, 478 (1 Eliz. I, c. 21; 5 Eliz. I, c. 31). The subsidies of 1566 and 1571 were not suspended due to the collection of the mises as indicated by Elton, but rather because of the delayed collection of earlier subsidies, themselves not received because of the mise payments: ibid., pp. 518, 581 ( 8 Eliz. I, c. 18; 13 Eliz. I, c. 27); Elton, 'Wales', p. 95. 
achieved, for Wales did not possess any national institutions where common policy could have been forged. ${ }^{49}$ Whatever its history, the petition testifies to the fact that collective action in parliament on behalf of the principality was feasible.

Co-operative action was probably also behind the act passed in 1544, which addressed ambiguities surrounding the payment of Welsh borough representatives as laid down by the first union act. Although Welsh contributory boroughs (in addition to the county town) were made collectively liable for paying each burgess's wages, the first union act had not specified directly any right on their part to vote. This apparent oversight had repercussions when the first batch of M.P.s submitted claims for their wages from these towns, and the act of 1544 set out to clarify the matter by stating their right to vote as well as liability for payment. ${ }^{50}$ There can be little doubt that this legislation was promoted by Welsh interests within the Commons, and, as in the case of general taxation, it is probable that its universality of application occasioned a co-operative effort by a number of Welsh members. ${ }^{51}$ Although such instances of unity do appear to have occurred in Tudor parliaments, it must be acknowledged that these were exceptional. More usually, Welsh interests were fragmented into smaller groups or lobbies representing particular economic or geographical concerns which did not necessarily enjoy the support of other members from the principality.

Historians have stressed the ineffectiveness of Welsh M.P.s in the Tudor period through the tendency for Welsh measures to be introduced in the Lords rather than the Commons. Referring to the mises petition of 1559, Dodd commented that the Welsh should have approached the Lords rather than their own representatives shows how little the idea of representation had impressed them' ${ }^{52}$ Elton also expressed consternation that it was the Lords rather than 'the taxpayers' proper representatives in the Commons' who moved for provisos in the subsidy bills..$^{53}$ However, Dodd and Elton failed to account for the fact that, with the leaders of feudal society present, the house of lords was the appropriate place to discuss the implications of a feudal levy. In addition, the principle of the mise directly concerned individuals in the Lords who remained lords marcher in Wales, as the practice of levying mises when a new lord came into his inheritance continued after the union and these individuals would wish to see such feudal perquisites safeguarded. ${ }^{54}$ Dodd and Elton's comments also raise

\footnotetext{
${ }^{49}$ The council in the marches at Ludlow was a 'national' institution, but it was an appendage of the privy council and a law court rather than a representative body where delegates of the Welsh localities met.

${ }^{50}$ Edwards, 'Parliamentary Representation', pp. 5-9; idem, 'The Parliamentary Representation of the Welsh Boroughs in the Mid-Sixteenth Century', Bulletin of the Board of Celtic Studies, XXVII (1976-8), 426-7; S.R., III, 969-70 (35 Hen. VIII, c. 11). These problems can be best seen in the case of Thomas Kynnyllyn, burgess for Monmouth in 1542, who brought a suit against five 'contributory boroughs' while at parliament, complaining that they 'utterly refused' to pay his wages whereby he was 'put to great losse and hynderance $\&$ is ... therby undon $\&$ is not hable to lye here any longer': P.R.O., C1/1020/49.

${ }^{51}$ Peter R. Roberts, 'The English Crown, the Principality of Wales and the Council in the Marches, 1534-1641', in The British Problem, c.1534-1707, ed. Brendan Bradshaw and John S. Morrill (1996), p. 129.

${ }^{52}$ Dodd, 'Apprenticeship', p. 11; Elton, 'Wales', pp. 107-8.

${ }^{53}$ However, compare this with his comments in Parliament, 1559-81, p. 159. See also Dodd, 'Apprenticeship', p. 11.

${ }^{54}$ For example, see K. Lloyd, 'The Privy Council, Star Chamber and Wales, 1540-1572', University of Wales (Swansea), Ph.D., 1987, pp. 203-4; B.L., Add. MS 36926, f. 9; P.R.O., C78/84/10; Cardiff
} 
the issue of the extent to which a notion of representation was present among Welsh members and their constituents during this period, and how the principality's M.P.s viewed their role within the assembly. Against the comments of Dodd and Elton should be considered recent 'revisionist' work on parliament which has emphasized the interdependence of the two houses, and highlighted the fact that they operated as an organic whole. ${ }^{55}$ Measures initiated in the Lords should not necessarily be divorced from members of the Commons and ideas of representation. ${ }^{56}$ It does not seem viable, for example, to isolate those bills which started in the Lords from the Welsh M.P.s in the lower House. ${ }^{57}$ Although this may demonstrate that the Welsh members frequently were not confident enough to sponsor measures themselves, equally it suggests the successful use of parliament as an institutional body. Indeed, it could even be argued that initiation of measures in the Lords, which had a higher success rate of actually achieving legislation, was a more effective use of parliament than reliance solely upon members in the Commons. ${ }^{58}$ Successful Welsh bills were largely introduced in the Lords while the majority of measures brought into the lower House rarely achieved a second reading. This coincidence could reflect the intervention of the triers and receivers of petitions, who indicated Crown approval for a bill at the opening of the session by assigning it to the upper House in an effort to prevent loss in the greater welter of business in the lower. ${ }^{59}$ This puts a very different slant on Elton's statement that the 'Welsh gentry and boroughs looked not to the men they sent to Westminster but to noble patrons', which oversimplifies the matter.

It has already been suggested that the petition presented to the Lords in 1559 regarding the mises probably originated with Welsh members in London. Other instances also point to a constructive dialogue between the Welsh in the Commons and their social superiors in the Lords. The act of 1566 for Merionethshire which rectified an arrangement whereby its criminals could be tried in Anglesey or Caernarvonshire, was a private measure introduced in the Lords. ${ }^{60}$ Its sponsor there may have been the earl of Leicester, and it is unlikely to be coincidental that the knight for Merioneth in this parliament was Leicester's chief agent in North Wales, Ellis Price of Plas Iolyn. ${ }^{61}$ Similarly the bill for the transfer of sessions from Newborough to Beaumaris in Anglesey was conceived by the Bulkeley family as a weapon against their rivals

${ }^{54}$ (continued) Central Library, MS 83, f. 7; N.L.W., Bute MSS M25/26, M26/29-32; Badminton MSS 2024, 2141; Pentice and Margam MS 5770.

${ }^{55}$ Michael A. R. Graves, The Tudor Parliaments. Croun, Lords and Commons, 1485-1603 (Harlow, 1985); David L. Smith, The Stuart Parliaments, 1603-1689 (1999).

${ }^{56}$ Michael A. R. Graves, The House of Lords in the Parliaments of Edward VI and Mary I. An Institutional Study (Cambridge, 1981), pp. 153-5.

${ }^{57}$ For the connexions between Lords and Commons, see Helen Miller, 'Lords and Commons: Relations Between the Two Houses of Parliament, 1509-1558', ante, I (1982), 13-24; David Dean, 'Patrons, Clients and Conferences: The Workings of Bicameralism in the Sixteenth Century English Parliament', in Bicameralisme. Tweekamerstelsel Vroeger en nu, ed. W.H. Blom, W.P. Blockmans and H. de Schepper (The Hague, 1992), pp. 217-22.

${ }^{58}$ Graves, Tudor Parliaments, pp. 139, 141. On the advantages of initiating legislation in the Lords, see Dean, Law-Making, pp. 11-12.

${ }^{59} \mathrm{I}$ am grateful to Alasdair Hawkyard for this point.

${ }^{60}$ Elton, 'Wales', p. 93; L.J., I, 657; S.R., IV, 522 (8 Eliz. I, c. 20).

${ }^{61}$ Dudley Papers (the marquess of Bath, Longleat House, Wilts.), II, f. 307; H.G. Owen, 'Family Politics in Elizabethan Merionethshire', Bulletin of the Board of Celtic Studies, XVIII (1958-60), 187. 
on the island, but was initiated in the upper House. ${ }^{62}$ This is attributable to the fact that Sir Richard Bulkeley was a client of John Dudley, earl of Warwick, and served him as deputy mayor and constable of Beaumaris. Sir Richard's kinsman, William Bulkeley of Llangefni, was the family's representative in the Commons and doubtless it was he who acted in concert with the earl to promote the measure. ${ }^{63}$ The bill for the Caernarvon sessions was introduced in the Lords, but the petition from the Conway burgesses stated explicitly that the 'preferrers of the ... bill are the knight and burgesse ... for the countie and towen of Carnarvan' ${ }^{64}$ In such cases, it would appear reductionistic to assert that the promotion of bills in the upper House by-passed interests in the Commons and thus negated any concept of representation on the part of Welsh members or their constituents. A more satisfying explanation acknowledges the connexions between members in the Commons and those in the Lords which were a key factor in achieving parliamentary success. Themes of representation, links with the aristocracy, and the parliamentary strategies employed by Welsh interests, were all present in the contentious passage of a bill to rebuild Cardiff bridge in the Elizabethan period. Discussion of this initiative will form the basis for the rest of this article.

In 1575 the bridge across the River Taff outside Cardiff collapsed. The question of who should pay for its reconstruction was fraught as the county maintained that Cardiff should shoulder a large part of the burden, while the townsmen looked to the county for substantial assistance. It was agreed that a benevolence should be levied for the bridge but the county's money come in very slowly and construction was delayed. This delay and the continued bickering between the town and county over interpretation of the relevant statute for apportioning costs (22 Hen. VIII, c. 5), caused the Cardiff men to promote a bill in parliament which made the county liable to pay four-fifths of the cost of reconstruction and required that the work be completed within two years. The county gentlemen, meanwhile, opposed the bill vigorously, probably fearing that it would be cited as a precedent for maintaining a number of other bridges in Glamorganshire. ${ }^{65}$ The controversy over Cardiff bridge has been studied previously by Penry Williams and Sir Geoffrey Elton, but here I wish to draw some conclusions from the evidence surrounding the case regarding Welsh attitudes to, and involvement with, parliament, which have not yet received attention. ${ }^{66}$ The first of these revolves about the tactics employed by the two sides in respectively promoting and resisting the passage of the bill. Its promoter was the knight for Glamorganshire, William Mathew of Radyr near Cardiff, who had

\footnotetext{
${ }^{61}$ (continued) For a more critical view of Leicester's involvement with his clientele's business in parliament, see S. L. Adams, 'The Dudley Clientéle and the House of Commons, 1559-1586', ante, VIII (1989), 231-3.

${ }^{62}$ L.J., I, 347, 351, 353.

${ }^{63}$ Edwards, 'Crynrychiolaeth a Chynnen', pp. 63-4; H.P., 1509-58, I, 267-8, 540.

${ }^{64}$ P.R.O., SP 12/176, f. 162.

${ }^{65}$ In the early eighteenth century some county gentry claimed that the statute had been used to exact unjust maintenance for weirs on the River Taff: P.R.O., C106/100, pt. 1.

${ }^{66}$ Penry Williams, 'Controversy in Elizabethan Glamorgan: The Rebuilding of Cardiff Bridge', Morgannug, II (1958), 38-46; Glamorgan County History, ed. Williams, pp. 181-3; Elton, 'Wales', pp. 97-9.
} 
been returned at a by-election in 1577 and whose alliance with the Glamorgan Herberts and the second earl of Pembroke was to be a determining factor in the struggle over the bill. That Mathew had decided to introduce a bill was known long before the parliament reopened in 1581, and the county gentry exerted themselves in trying to sway the opinion of influential figures such as Sir Henry Sidney, lord president of Wales. ${ }^{67}$ However, their efforts to lay the groundwork for frustrating the measure before it was even introduced were unsuccessful. The county interests bewailed the fact that Mathew, in presenting his bill, left them bereft of a voice in the Commons. Nevertheless, they attempted to exert pressure where they could to stymie the measure. The county lobby, led by Sir Edward Stradling of St Donat's, produced a list of instructions 'to staie the bill exhibited for the makinge of the bridge of Cardif' ${ }^{68}$ It expressed the willingness of the county to contribute to the work, but objected to the proposed apportionment of costs. The survival of this paper among both the state papers and the earl of Northumberland's archive, suggests that it was sent to nobles and influential figures on the council who could frustrate the bill in the Lords. Sir Edward Mansell and the Glamorgan gentlemen also wrote directly to peers such as Northumberland and Pembroke, beseeching them that 'you by yourself and your frindes ... bee a mean[s] to stay this unnaturall attempt'. ${ }^{69}$ Mansell was even more explicit in a letter to Sir Henry Sidney, requesting he write to the Earl of Pembroke 'that he comaunde the knight of our shere \& burges of parliament for this conte [county] and town that they desist from preferring that bill' ${ }^{70}$ In a co-ordinated effort, the county lobby also approached the privy council after the bill had received its second reading in the Commons, 'for preventing wherof we are to become humble suters unto your Lordships'. They requested that if the bill passed both houses, the council would 'affurther us by peticon to her Majestie for stay of her royall assent'. ${ }^{71}$ The bill passed rapidly through parliament and in desperation the county gentlemen petitioned the queen in a final effort to quash it, claiming that on account of Mathew's partisanship 'the matter was not opened' in the Commons and that the truth of the issue had not been heard. ${ }^{72}$ At every parliamentary stage, therefore, the county interests lobbied vigorously for the bill to be frustrated but they were unsuccessful and it passed onto the statute book. ${ }^{73}$ Essential in achieving this result was the fact that the second earl of Pembroke, who owned the lordship of Cardiff and had enormous influence there, supported the case of the town.

Sir Edward Mansell openly acknowledged that he had sent his son Thomas together with Miles Button, to 'solicytte our cause first to my Lord of Pembrok and my Lord of Leicescer, to the 3 estates, and yf they can not bridle the knight [for Glamorgan] and burges [for Cardiff], then which failing, to her Majestye'. ${ }^{74}$ In their frantic efforts

\footnotetext{
${ }^{67}$ N.L.W., Penrice and Margam MSS 1821, 3585.

${ }^{68}$ Northumberland Papers (the duke of Northumberland, Alnwick Castle, Northumberland) III, ff. 77-9; P.R.O., SP $12 / 148$, ff. 33-34v.

${ }^{69}$ Northumberland Papers III, ff. $101 \mathrm{r}-\mathrm{v}, 103$; N.L.W., Penrice and Margam MS L.27.

${ }^{70}$ N.L.W., Penrice and Margam MS 1821.

${ }^{71}$ Ibid., 1822.

72 lbid., 3011.

${ }^{73} \mathrm{SR}$, IV, 673-4 (23 Eliz. I, c. 11).

${ }^{74}$ N.L.W., Penrice and Margam MS 1821.
} 
to block the bill, however, Mansell and his associates overstepped the boundaries of proper relations with the nobility, and the earl of Leicester upbraided them for 'yor manner of dealing ... to wryte to so many noble men, particularly in it as you have done ... [which] can be thought to proceade but ... from a mere factious devise' ${ }^{75}$ It is also interesting to note that as a response to their concerted lobbying, and possibly as part of a wider investigation occasioned by the agitation of the shire group, William Mathew presented a defence of 'cawses' that moved him to proffer the bill. ${ }^{76}$ This picture of energetic lobbying by both parties does not agree with the view of the Welsh in the Tudor period as uninterested in parliament and uncertain about its procedures. Indeed, the county gentlemen canvassed an impressive array of personalities when their direct leverage in parliament was negated by the defection of their own member.

The Cardiff bridge case also reveals a good deal about the notion of representation and how contemporaries conceived of the relationship with their member in parliament. Elton questioned the existence of such a relationship as a development of his argument about the Welsh proclivity for using the house of lords, noting 'what use was William Mathew to the shire that had elected him?'77 This is a very valid point, for if Mathew, elected after the collapse of the bridge, abandoned the interests of those he was meant to represent, then surely the bonds between electors and elected were tenuous indeed. However, the overriding theme of the stream of letters and petitions produced by Mansell and his associates throughout was their sense of betrayal, that the normative relationship between the Glamorganshire gentry and their parliamentary representative had been violated by Mathew's actions. They denigrated Mathew's behaviour as an 'unaturall attempte', language which conveys not only their opposition, but, more profoundly, the notion that his actions had transgressed the contract between a member and his constituents. ${ }^{78}$ They complained he had been 'chosen for us and waged by us yet [he] furthereth the cause of oure adversaryes', giving a clear sense of the relationship understood to exist between election, payment and accountability. ${ }^{79}$ Their outrage was articulated most eloquently by Sir Edward Mansell in a letter to Sir William Herbert of St Julian's where he recalled how 'Mr Mathew had falsified his faythe to his whole contrey at the tyme he was retayned to serve the same trewlye'. ${ }^{80}$ Such statements demonstrate that a sense of representation and accountability were inherent elements in the election of a parliamentary member in Tudor Glamorgan, and there is no reason to believe that political sensibilities were more developed here than elsewhere in Wales. It should also be noted that these values were implicit and generally would not have been vocalized, and have only survived in this case because of Mathew's actions against the county interest. The Cardiff bridge affair, then, helps demonstrate that Welshmen in

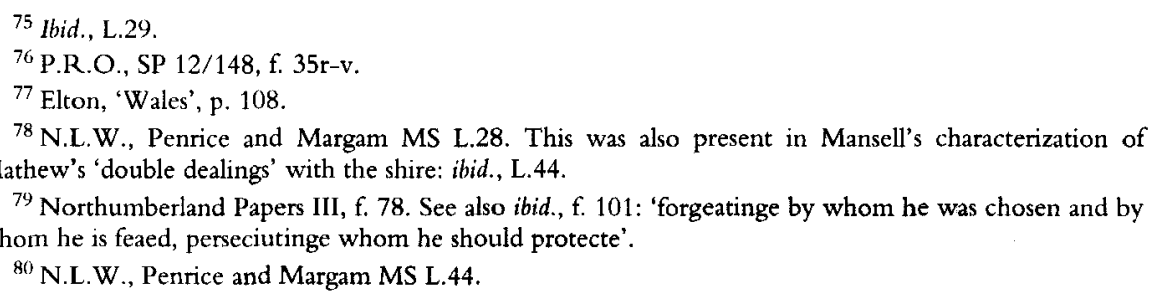


the Tudor period did engage with parliamentary politics and were well appraised of the tactics for prosecuting (or attempting to frustrate) business at Westminster. This episode also shows how politics in a constituency such as Glamorganshire could not be divorced from noble networks. ${ }^{81}$ The patronage of the earl of Pembroke was essential for the success of the town's case. Yet the approaches made to the queen, the privy council and a number of peers by Mansell and his group, should alert us to the reductive nature of assessing political engagement in Wales simply upon the basis of the house in which legislative measures began their life. Parliamentary politics was not conducted solely within the Commons, but informed a whole variety of arenas where pressure could be applied and measures brought to fruition or dashed. ${ }^{82}$

This re-assessment of Welsh politics under the Tudors has not attempted to claim that the Welsh were parliamentary operators par excellence. At first sight, the inference that the Welsh contributed little to the work of the house of commons has much to commend it. However, it is contended here that the evidence, albeit highly deficient, does not support the argument that the Welsh failed to engage with parliament until the accession of Charles I. No doubt there was something of a parliamentary 'apprenticeship' served by Welshmen, but it was not as prolonged nor as profound as has been thought. Indeed, when quantified, Welsh activity in parliament emerges as comparable with many of the regions in England which had much greater experience of representation at Westminster. ${ }^{83}$ The search for collective Welsh parliamentary activity in this period may resemble the hunting of the snark, but acknowledging the role of particular localities or economic interests within the principality reveals a rather different picture. During the sixteenth century the Welsh evidently were not a dynamic group in the Commons, but they did engage with parliament and recognized its potency, and the evidence presented here reveals that the Tudor period was not the extended parliamentary 'prologue' it has previously been depicted.

${ }^{81}$ Penry Williams, 'Court and Polity Under Elizabeth I', Bulletin of the John Rylands Library, LXV (1983), 265-7.

82 David Dean, 'Revising the History of Tudor Parliaments', Historical Jour., XXXII (1989), 410.

${ }^{83}$ I am most grateful to Alasdair Hawkyard for this information which is derived from his forthcoming introductory survey for the 1509-58 volumes for the History of Parliament Trust. 